\title{
Romanian bentonite and fly ash characterization and their use in heavy metal "in-situ" immobilization in polluted soils
}

\author{
Săndica Liliana Gherghe $^{1, *}$, Ildiko Anger ${ }^{1}$, Georgiana Moise ${ }^{1}$, and Roxana Trusca $^{2}$ \\ ${ }^{1}$ National Research and Development Institute for Nonferrous and Rare Metals, 102 Biruintei Blvd, Pantelimon, Romania \\ ${ }^{2}$ Politehnica University Bucharest, 313 Independentei Splai, Bucharest, Romania
}

\begin{abstract}
This article presents the characterization of the Romanian bentonite and fly ash, using different techniques: FAAS, XRD, FT-IR, SEM and EDAX and their evaluation as sorbents for heavy metals immobilization in polluted soils coming from mining and metallurgical activities. The applicability of bentonite and fly ash for $\mathrm{Pb}$ (II) and $\mathrm{Zn}$ (II) immobilization was studied using aqueous solutions of these metals. The influence of the $\mathrm{pH}$ and contact time were studied. The results shown that the Romanian bentonite and fly ash could be used for $\mathrm{Pb}$ (II) and $\mathrm{Zn}$ (II) immobilization in polluted soils from brownfields.
\end{abstract}

\section{Introduction}

Heavy metals, such as lead, copper, zinc, nickel, cadmium, chromium are present in soil as natural components, but their presence in environment has increased due to the human activities. The heavy metals are released into the environment through various activities such as mining, energy and fuel production, electroplating, wastewater treatment [1]. The zinc is essential for life and for a healthy body and it is a common micronutrient in trace amounts [2]. In excess, zinc can be harmful and causes zinc toxicity. A long-time exposure to $\mathrm{Zn}$ (II) is harmful for human health. The free zinc ions in solution are highly toxic to plants, invertebrates and human. The lead is extremely toxic and it has adverse effects as it accumulates in the body. All lead compounds are cumulative poisons. In body, lead affects in special the neuronal system.

To reduce the risks associated to heavy metals presence in environment various treatment techniques are used, like: ion exchange, biodegradation, oxidation, solvent extraction and adsorption. The adsorption technique remains widely preferred due to its simplicity of design and operation, cost effectiveness, high efficiency and flexibility [3]. This method is usually used for waste water treatment, but the treatment of polluted soils with heavy metals is also based on the adsorption process. Different natural materials (clay, zeolite) or byproducts (fly ash) are used for heavy metal immobilization in soil.

The fly ash is a by-product from electric power plant which utilizes lignite coal as fuel $[4,5]$. The fly ash is removed from the emission control devices and it is transported and deposited in open dump where is accumulated in a large amount. For this reason, its disposal creates serious environment problems. The worldwide studies identify possibilities for fly ash use, such as: road construction, construction materials, cement industry, soil amendment and adsorbent material for the adsorption of heavy metals from waste waters $[4,6]$. The major constituents of fly ash are silica, alumina, and iron oxide.

The clay minerals have a small grain size and a specific mineralogical structure which results in specific properties. The most important of these properties are the large specific surface area and the resulting ability to adsorb cations [7]. Therefore, clay minerals are used in a large variety of environmental applications. Clay minerals are composed from fine-grained aluminosilicates.

The aim of this paper is to assess the capacity of bentonite (natural clay) and fly ash to adsorb $\mathrm{Pb}$ (II) and $\mathrm{Zn}$ (II) ions from aqueous solutions. For this reason, the physical, chemical and mineralogical composition of bentonite and fly ash was determined. Batch adsorption experiments were performed to investigate the effect of $\mathrm{pH}$ and contact time on the adsorption of $\mathrm{Pb}$ (II) and $\mathrm{Zn}$ (II) ions onto these materials.

\section{Materials and methods}

The fly ash samples were obtained from power plant Govora, Romania. This power plant use lignite from Berbesti-Alunu coals mine. The fly ash was capture from the dry emission control system. In accordance with SR EN 450-1" Fly ash for concrete - Part 1, Definition, conditions and standards" these categories of fly ash, can be used as admixture type II for concrete, binder and cement slurry.

The bentonite was obtained from Orasul Nou (Maramures county) natural deposit. This bentonite is less commercialized.

\footnotetext{
* Corresponding author: gliliana@imnr.ro
} 


\subsection{Characterization}

The chemical composition of the fly ash and bentonite was determined by inductive coupled plasma optical emission spectrometer (ICP-OES) SPECTROFLAME ICP model P, Germany and Flame Adsorption Atomic Spectroscopy (FAAS).

The mineralogical composition of the bentonite and fly ash was determined by the X-ray diffraction analysis for the qualitative evaluation of the common and predominant phases within the ash, using a BRUCKER D8 ADVANCE diffractometer and software package DIFRAC ${ }^{\text {plus }}$ BASIC Released 2006 (Brucker) and ICDD PDF-2 database release 2006.

The optical microscopy analysis were performed using a Zeiss - Jena - Axio IMAGER Alm microscope.

The scanning electron microscopy (SEM-EDAX) was used to determine the morphological and quantitative characteristics of the materials.

The IR spectra of bentonite was obtained using a FTIR ABB MB 3000 spectrometer.

The leaching tests of fly ash were conducted in accordance with the EN 12457-1 si EN 12457-2 standards.

\subsection{Preparation of the heavy metal solutions}

Stock solutions of $\mathrm{Pb}$ (II) and $\mathrm{Zn}$ (II) (containing $1000 \mathrm{mg}$ metal/L) were prepared using lead nitrate $\left(\mathrm{Pb}\left(\mathrm{NO}_{3}\right)_{2}\right.$ and zinc sulphate heptahydrate $\left(\mathrm{ZnSO}_{4} \cdot 7 \mathrm{H}_{2} \mathrm{O}\right)$ of analytical purity. The $\mathrm{pH}$ adjustments were performed using nitric acid, sulphuric acid or sodium hydroxide $0.1 \mathrm{M}$ aqueous solutions.

\subsection{Experimental}

The batch adsorption experiments were carried out at room temperature $\left(22^{0} \mathrm{C} \pm 3^{0} \mathrm{C}\right)$. One hundred milliliters of solution containing $100 \mathrm{mg} / \mathrm{L}$ of $\mathrm{Pb}(\mathrm{II})$ or $\mathrm{Zn}$ (II) were treated with the desired amount of adsorbent in $250 \mathrm{~mL}$ conical flasks. The mixtures were stirred for $0-240 \mathrm{~min}$. At the end of each time period, the adsorbent was removed by filtration and the filtrate was analyzed for residual metal concentration by atomic absorption spectroscopy and FAAS

The efficiency of the removal of $\mathrm{Pb}$ (II)and $\mathrm{Zn}$ (II) from solution was calculated using Eqn.1 [1,8]

$$
\text { Removal efficiency } \%=\frac{C_{0}-C_{f}}{C_{0}} \times 100
$$

where: $\mathrm{R}$ is the removal efficiency $(\%), \mathrm{C}_{0}$ is the initial metal concentration $(\mathrm{mg} / \mathrm{L}), \mathrm{C}_{\mathrm{f}}$ is the final metal concentration $(\mathrm{mg} / \mathrm{L})$.

\section{Results and Discussions}

\subsection{Bentonite and fly ash characteristics}

The oxidic composition of the bentonite and fly ash is presented in table 1.

Table 1. The oxides composition of the bentonite and fly ash, [weight \%].

\begin{tabular}{|c|c|c|c|c|c|c|c|c|c|}
\cline { 2 - 11 } \multicolumn{1}{c|}{} & $\mathbf{S i O}_{2}$ & $\mathrm{Al}_{2} \mathbf{O}_{3}$ & $\mathbf{C a O}$ & $\mathbf{M g O}$ & $\mathbf{F e}_{2} \mathbf{O}_{3}$ & $\mathbf{N a}_{2} \mathbf{O}$ & $\mathbf{K}_{2} \mathbf{O}$ & $\mathbf{H}_{2} \mathbf{O}$ & $\begin{array}{c}\mathbf{L O I}^{*} \\
\left(\mathbf{1 0 0 0}^{*} \mathbf{C}\right)\end{array}$ \\
\hline Bentonite & 68.49 & 10.77 & 1.19 & 1.23 & 1.80 & 4.38 & 0.80 & 11.37 & - \\
\hline Fly Ash & 52.11 & 20.2 & 7.14 & 2.33 & 8.14 & - & - & 0.14 & 3.06 \\
\hline
\end{tabular}

The fly ash has a low content of $\mathrm{CaO}$. It is siliceous type fly ash, with low loss of ignition.

The bentonite has a ratio of $\mathrm{SiO}_{2} / \mathrm{Al}_{2} \mathrm{O}_{3}=6.36$, $\mathrm{SiO}_{2} / \mathrm{Fe}_{2} \mathrm{O}_{3}=38.05$ and $\mathrm{MgO} / \mathrm{Fe}_{2} \mathrm{O}_{3}=0.69$. In the fly ash, the amorphous phase is $61.5 \mathrm{wt} \%$ and crystalline phase is $38.5 \mathrm{wt} \%$, according to results obtained from XRD analysis. The main crystalline phases are: $45 \mathrm{wt} \%$ quartz $\quad\left(\mathrm{SiO}_{2}\right), \quad 21 \quad \mathrm{wt} \%$ anorthite (calcium aluminosilicate $\left.\mathrm{Ca}_{0.88} \mathrm{Al}_{1.77} \mathrm{Si}_{2.23} \mathrm{O}_{8}\right), 14 \mathrm{wt} \%$ anhydrite $\left(\mathrm{CaSO}_{4}\right), 9$ wt $\%$ gehlenite $\left(\mathrm{Ca}_{2} \mathrm{Al}[\mathrm{AlSiO}]_{7}\right), 6 \mathrm{wt} \%$ hematite $\left(\mathrm{Fe}_{2} \mathrm{O}_{3}\right)$ and $5 \mathrm{wt} \%$ magnetite $\left(\mathrm{Fe}_{3} \mathrm{O}_{4}\right)$ (figure 1).

The main crystalline phases in bentonite are beidellite/montmorillonite ( $>70 \mathrm{wt} \%$ ), cristobalite, albite (potassian and calcian), quartz (figure 2).

The optical microscopy analysis for fly ash highlights very well the amorphous and crystalline phases. In these phases, the grains of hematite and magnetite appear. Figure 3 shows the photo with the amorphous phase and hematite grain. The bentonite optical analysis presents the micro-crystalline phase (clay minerals) and some albite and quartz (figure 4).

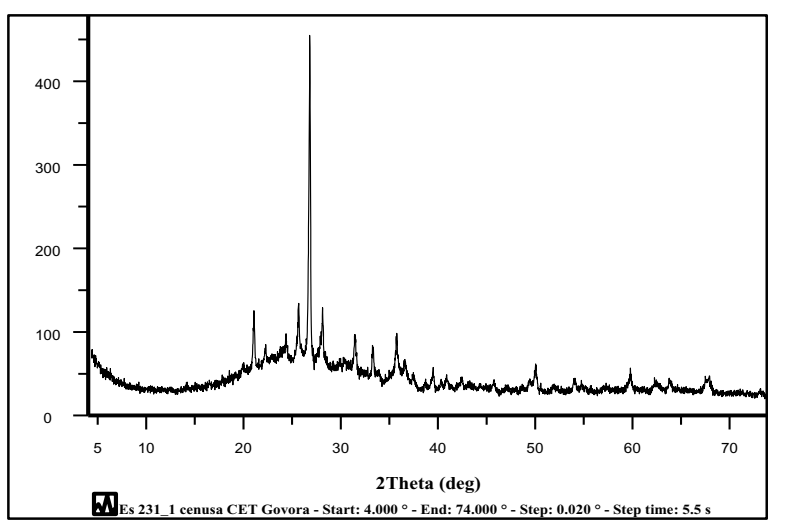

Fig. 1. Crystalline phases of fly ash determined by DRX.

The scanning electron microscopy (SEM) was used to determine the morphological characteristics and surface texture of the bentonite and fly ash.

SEM images of the fly ash Govora are presented in figure 5 and the EDAX spectrum of the fly ash is presented in figure 6 . 


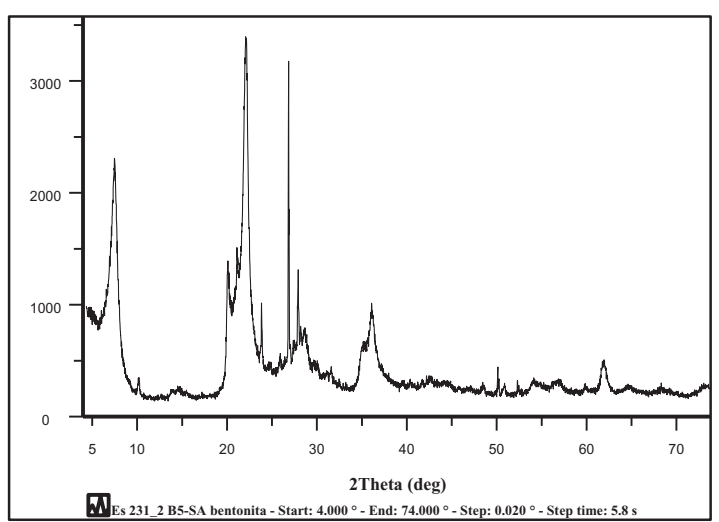

Fig. 2. Crystalline phases of the bentonite determined by DRX.

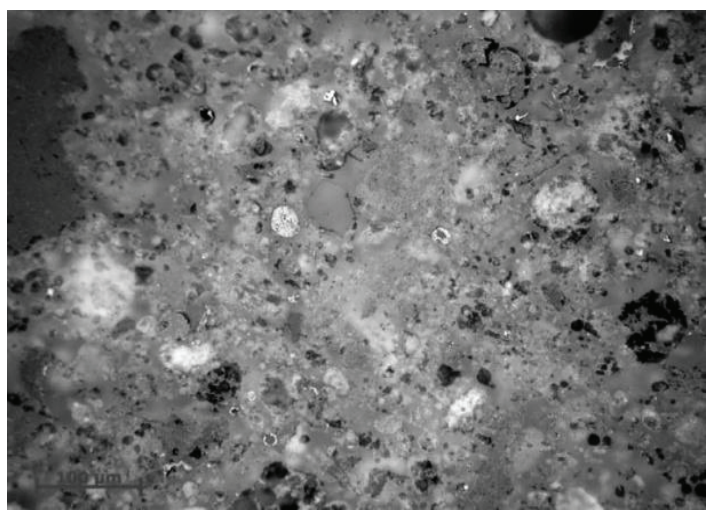

Fig. 3. The optical microscopy analysis of the fly ash.

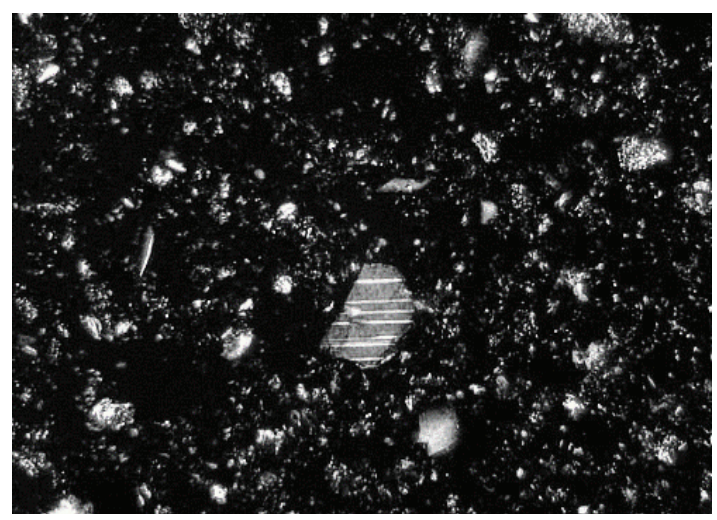

Fig. 4. The optical microscopy analysis of the bentonite.

The morphology of this ash is similar with the other ashes $[9,10,12]$. The fly ash is a fine powder, contains microspheres with diameter of 5-15 $\mu \mathrm{m}$. The EDAX analysis shows the presence of carbon, magnesium and iron too, near the constituent elements of the minerals mentioned by DRX. The bentonite is formed from grains with submicron size (figure 7). These grains form aggregates with size of $1-10 \mu \mathrm{m}$.

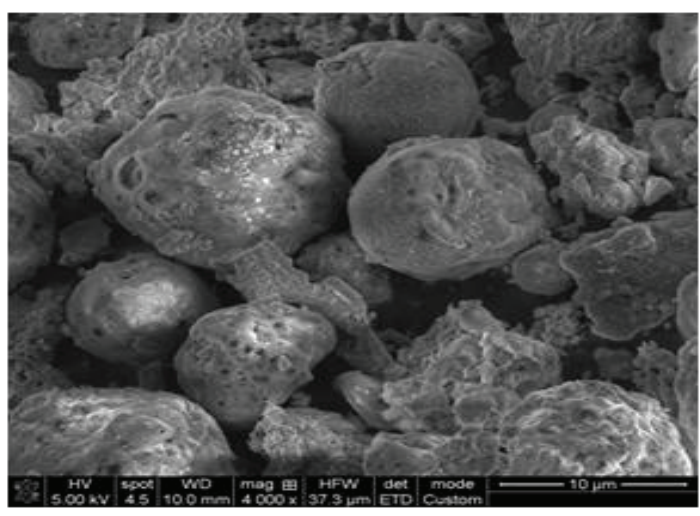

Fig. 5. SEM micrograph of the fly ash.

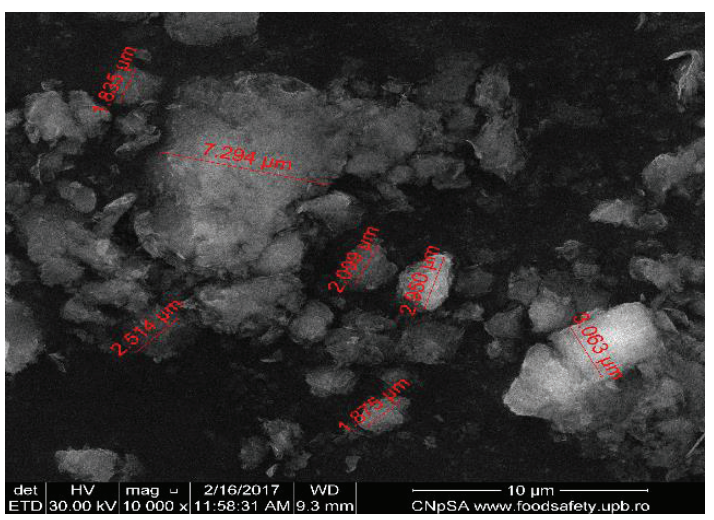

Fig. 6. SEM micrograph of the bentonite.

The EDAX analyses shown (figures 7,8 ) the silicon and aluminium as main elements which form the crystalline framework together with oxygen. The other elements $(\mathrm{Na}, \mathrm{Mg}, \mathrm{K}, \mathrm{Ca}$ and $\mathrm{Fe}$ ) could isomorphic substitute silicon in tetrahedral layer. Fe and $\mathrm{Mg}$ could substitute $\mathrm{Al}$ in octahedral layer. The negative charges will be compensated by $\mathrm{Na}, \mathrm{K}, \mathrm{Ca}, \mathrm{Fe}$ and $\mathrm{Mg}$.

The thermal analysis (DSC) shows three peaks (endotherm effects) situated at $96,5^{\circ} \mathrm{C}, 178^{\circ} \mathrm{C}$ and $673^{\circ} \mathrm{C}$. At $96,5^{\circ} \mathrm{C}$ and $178^{\circ} \mathrm{C}$ the adsorbed water is eliminated. The peak from $673^{\circ} \mathrm{C}$ is characteristic for bentonite (which has montmorillonite as main component) aluminium - iron - magnesium. Generally, the $\mathrm{MgO} / \mathrm{Fe}_{2} \mathrm{O}_{3}$ ratio in bentonite is less than 0.9. The studied bentonite has the $\mathrm{MgO} / \mathrm{Fe}_{2} \mathrm{O}_{3}$ ratio equal with 0.69 .

The $\mathrm{pH}_{\mathrm{pzc}}$ of bentonite was below 2. This shows that $\mathrm{Si}$ and $\mathrm{Al}$ were isomorphic substituted in the crystalline framework and the negative charges have permanent character and don't depend on $\mathrm{pH}$.

The FT-IR study (figure 9) of bentonite shows the characteristic peaks at $3632 \mathrm{~cm}^{-1}$ assigned for stretching vibration of $\mathrm{OH}^{-}$groups and characteristic for montmorillonite. 

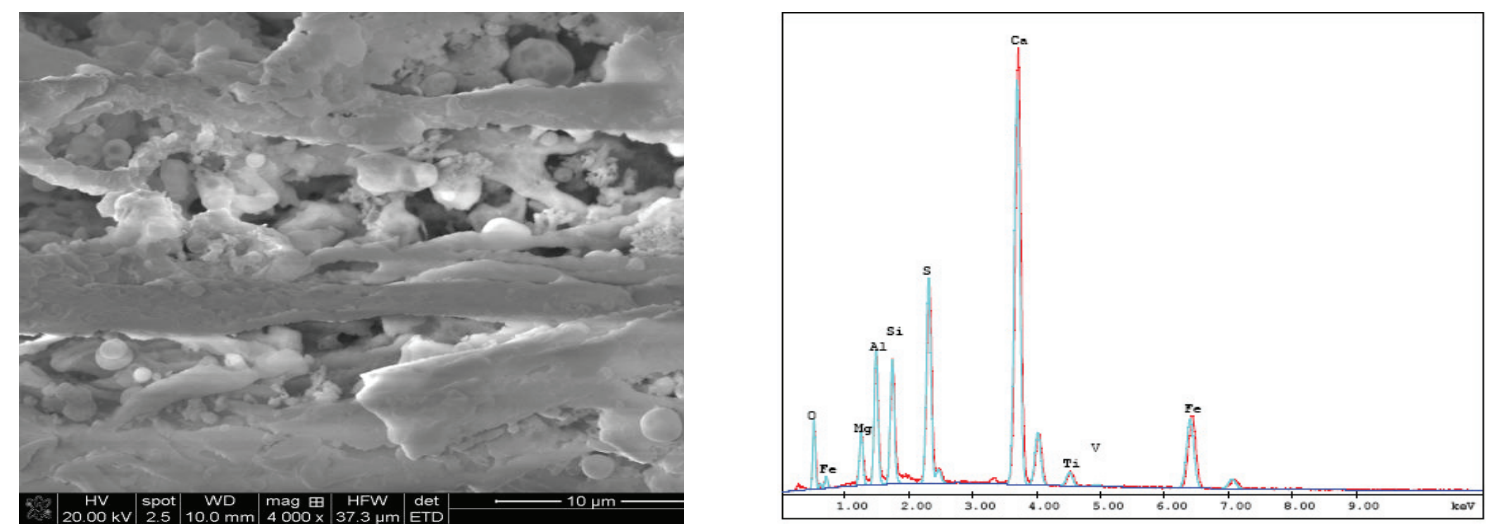

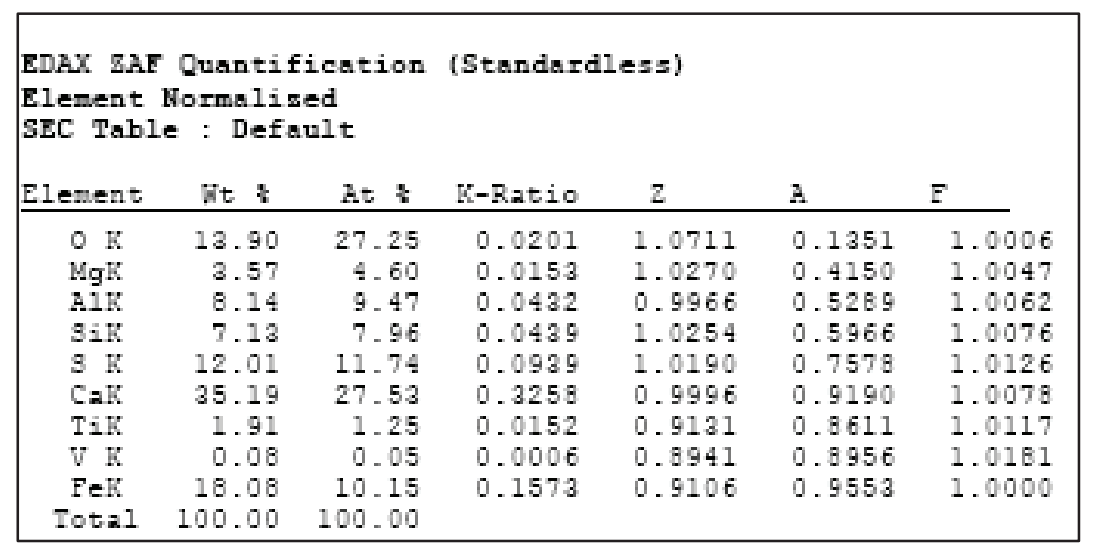

Fig. 7. EDAX of fly ash.
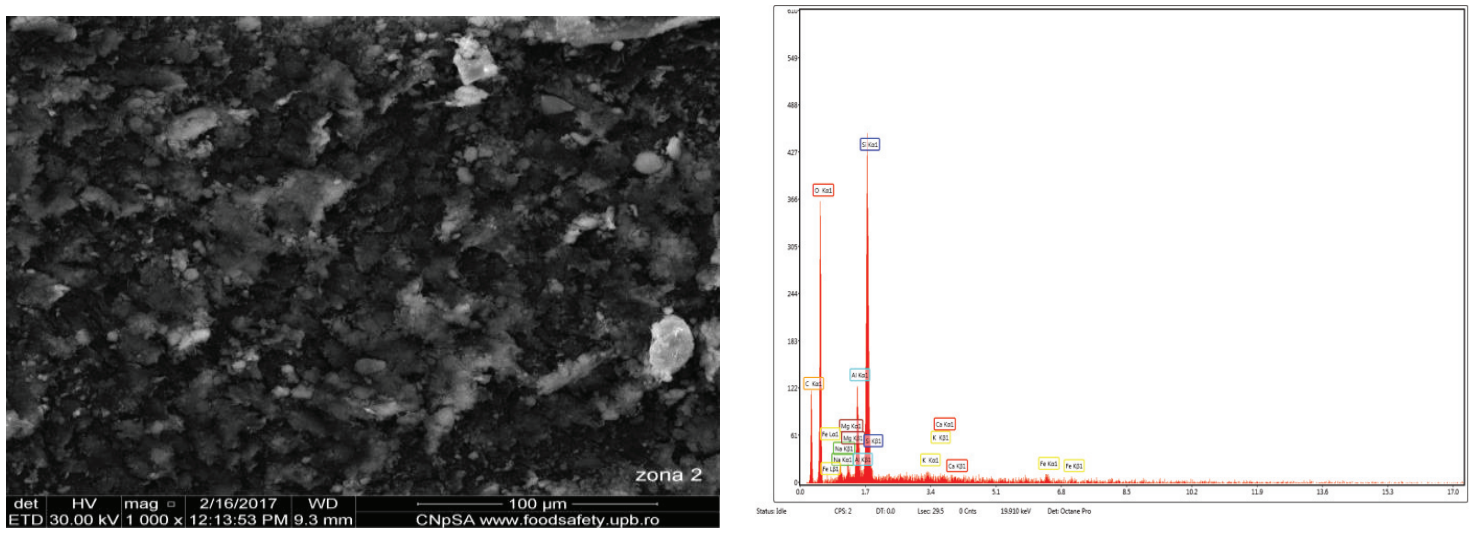

\begin{tabular}{|c|c|c|c|c|c|c|c|c|}
\hline Element & Weight, \% & Atomic, \% & Error, \% & Net Int. & K Ratio & Z & A & F \\
\hline O K & 59.11 & 71.4 & 9.91 & 57.79 & 0.2032 & 1.0336 & 0.3326 & 1 \\
\hline Na K & 3.91 & 3.29 & 24.14 & 4.63 & 0.0085 & 0.947 & 0.2273 & 1.0059 \\
\hline Mg K & 1.33 & 1.06 & 32.12 & 3.14 & 0.0043 & 0.9654 & 0.3288 & 1.0107 \\
\hline Al K & 7.43 & 5.32 & 12.02 & 25.45 & 0.0325 & 0.9316 & 0.463 & 1.0143 \\
\hline Si K & 26.42 & 18.18 & 7.65 & 106.19 & 0.1321 & 0.9539 & 0.5226 & 1.003 \\
\hline K K & 0.6 & 0.29 & 63.65 & 2.69 & 0.0044 & 0.8918 & 0.8191 & 1.0196 \\
\hline Ca K & 0.33 & 0.16 & 64.72 & 1.39 & 0.0027 & 0.9095 & 0.8745 & 1.025 \\
\hline Fe K & 0.87 & 0.3 & 61.56 & 2.7 & 0.0081 & 0.8194 & 1.0105 & 1.1142 \\
\hline
\end{tabular}

Fig. 8. EDAX of bentonite. 
Table 2. Concentration of heavy metals in leachate [17].

\begin{tabular}{|c|c|c|c|c|c|c|}
\hline \multirow{3}{*}{$\begin{array}{l}\text { Heavy } \\
\text { metal }\end{array}$} & \multicolumn{6}{|c|}{ Concentration limits } \\
\hline & \multicolumn{2}{|c|}{ Inert waste (RL) } & \multicolumn{2}{|c|}{ Non - hazardous waste (RL) } & \multicolumn{2}{|c|}{ Leachate } \\
\hline & $\begin{array}{c}\mathrm{L} / \mathrm{S}=2 \mathrm{l} / \mathrm{kg} \\
\mathrm{mg} / \mathrm{kg}\end{array}$ & $\begin{array}{c}\mathrm{L} / \mathrm{S}=10 \mathrm{l} / \mathrm{kg} \\
\mathrm{mg} / \mathrm{kg}\end{array}$ & $\begin{array}{c}\mathrm{L} / \mathrm{S}=2 \mathrm{l} / \mathrm{kg} \\
\mathrm{mg} / \mathrm{kg}\end{array}$ & $\begin{array}{c}\mathrm{L} / \mathrm{S}=10 \mathrm{l} / \mathrm{kg} \\
\mathrm{mg} / \mathrm{kg}\end{array}$ & $\begin{array}{l}\mathrm{L} / \mathrm{S}=2 \mathrm{l} / \mathrm{kg} \\
\mathrm{mg} / \mathrm{kg}\end{array}$ & $\begin{array}{c}\mathrm{L} / \mathrm{S}=10 \mathrm{l} / \mathrm{kg} \\
\mathrm{mg} / \mathrm{kg}\end{array}$ \\
\hline $\mathrm{Cu}$ & 0.90 & 2.00 & 25 & 50 & 0.02 & 0.12 \\
\hline $\mathrm{Ni}$ & 0.20 & 0.40 & 5.0 & 10 & 0.04 & 0.19 \\
\hline $\mathrm{Zn}$ & 2.00 & 4.00 & 25.0 & 50 & 0.42 & 4.79 \\
\hline $\mathrm{Pb}$ & 0.20 & 0.50 & 5.0 & 10 & 0.09 & 1.53 \\
\hline $\mathrm{Cd}$ & 0.03 & 0.04 & 0.6 & 1 & 0.02 & 0.10 \\
\hline
\end{tabular}

The peaks 3491,3410 and $1639 \mathrm{~cm}^{-1}$ are assigned for stretching and deformation vibration of $\mathrm{OH}^{-}$groups from adsorbed water in bentonite network; $918 \mathrm{~cm}^{-}$for stretching vibration of $\mathrm{OH}^{-}$from the $\mathrm{Al}_{2} \mathrm{OH} ; 795 \mathrm{~cm}^{-1}$ for $\mathrm{Fe}(\mathrm{II}) \mathrm{Fe}$ (III)OH group presence; peaks at 1043 and $627 \mathrm{~cm}^{-1}$ are attributed to the $\mathrm{Si}-\mathrm{O}$ and $\mathrm{Si}-\mathrm{O}-\mathrm{Al}$ vibrations [13-16].

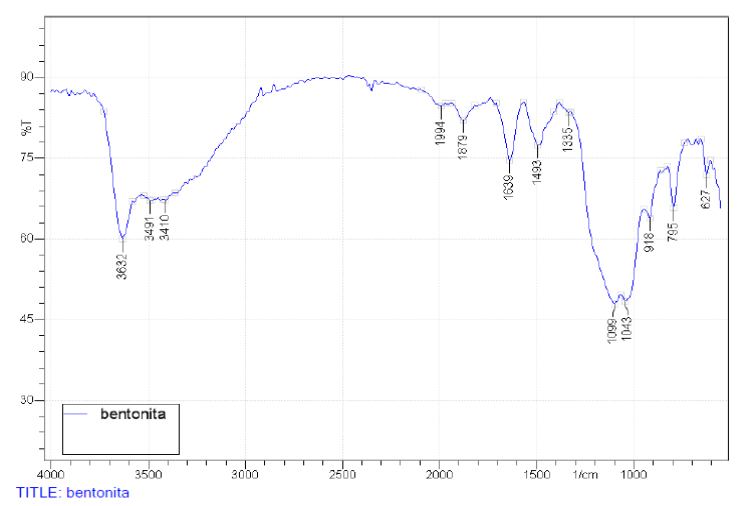

Fig. 9. The FT - IR spectra of bentonite.

The leaching test of the fly ash, presented in table 2 , shows that the leachates contain heavy metals below the standards for non-hazardous waste in accordance with national legislation (RL) [17].

\subsection{Adsorption tests}

\subsubsection{Effect of $p H$}

The removal efficiency was studied at $\mathrm{pH}$ values between 2.5 and 7.0. The influence of $\mathrm{pH}$ on the removal efficiency of $\mathrm{Pb}$ (II) and $\mathrm{Zn}$ (II) onto bentonite (B) and fly ash (FA) is presented in figure 10 . The $\mathrm{Pb}$ (II) removal efficiency on FA increases starting from $\mathrm{pH}=2.5$ until $\mathrm{pH}=5.0$, when the efficiency is maximum. The $\mathrm{Zn}$ (II) removal efficiency on $\mathrm{FA}$ was $95 \%$ at $\mathrm{pH}=7.0$. The $\mathrm{Zn}$ (II) removal efficiency is very low between $\mathrm{pH}=2.7$ 3.6. This should be explained with the presence of silica in fly ash. The silica could uptake either positive or negative contaminants depending on the solution $\mathrm{pH}$. The silicon, the central ion of silica, has electron affinity, giving the oxygen atoms bound to it low basicity. This enables the silica surface to act as a weak acid, which can react with water, forming silanol ( $\mathrm{SiOH})$ groups. As a result, at low $\mathrm{pH}$ the silica surface is positively charged and at high $\mathrm{pH}$ values is negatively charged $[18,19]$. The other solid materials, for example iron oxide (another constituent of FA), develops positive or negative charges also. In accordance with this theory, at $\mathrm{pH}=2.7-3.6$, the number of sites with negative charge is very low and only a very small quantity of $\mathrm{Zn}(\mathrm{II})$ ions can be fixed with electrostatic interactions on the silica surface. $\mathrm{Pb}$ (II) ions can be fixed both on the silica and iron oxide surface.

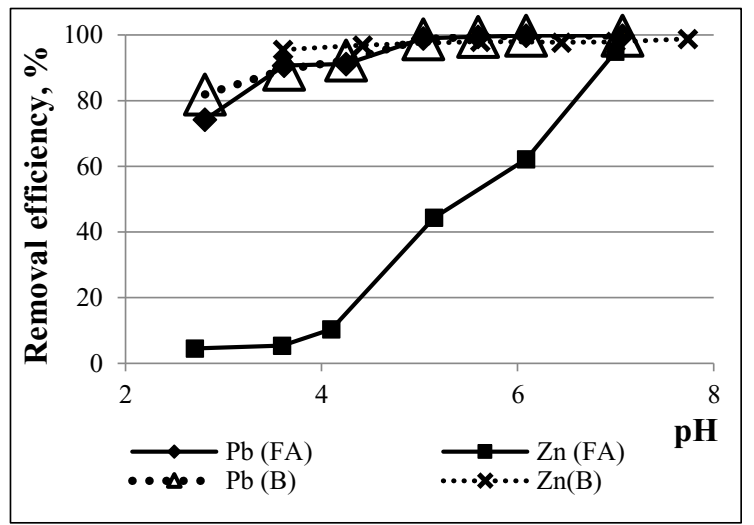

Fig. 10. Effect of $\mathrm{pH}$ on the $\mathrm{Pb}(\mathrm{II})$ and $\mathrm{Zn}(\mathrm{II})$ removal efficiency on bentonite (B) and fly ash(FA).

The removal efficiency of $\mathrm{Pb}(\mathrm{II})$ and $\mathrm{Zn}(\mathrm{II})$ on bentonite is high (above $80 \%$ ) even at low $\mathrm{pH}$. The removal of these ions from aqueous solution using $\mathrm{B}$ doesn't depend on $\mathrm{pH}$. The $\mathrm{pH}_{\mathrm{pzc}}$ of bentonite is below 2 , that means the bentonite surface above $\mathrm{pH}=2$ has negative charges. These negative charges result from isomorphic substitutions of $\mathrm{Si}$ in the tetrahedral layer and of $\mathrm{Al}$ in octahedral layer. The removal efficiency is maximum at $\mathrm{pH}=5.5$ for both $\mathrm{Pb}(\mathrm{II})$ and $\mathrm{Zn}(\mathrm{II})$.

\subsubsection{Effect of contact time}

The removal efficiency of heavy metal ions ( $\mathrm{Pb}$ (II) and $\mathrm{Zn}(\mathrm{II})$ ) from solution using bentonite and fly ash versus time is presented in figure 11 .

The results indicated that the $\mathrm{Pb}$ (II) and $\mathrm{Zn}$ (II) ions uptake increase with contact time, until an equilibrium is reached. The equilibrium was reached within 60 minutes for $\mathrm{Pb}(\mathrm{FA})$ and in 30 minutes for $\mathrm{Pb}(\mathrm{B})$. For $\mathrm{Zn}(\mathrm{FA})$, the equilibrium was obtained at 180 minutes and for $\mathrm{Zn}(\mathrm{B})$ in 120 minutes. The adsorption capacity obtained for $\mathrm{Pb}(\mathrm{FA})$ was $19.9 \mathrm{mg} / \mathrm{g}$ at 60 minutes and for $\mathrm{Zn}(\mathrm{FA})$ was $5.31 \mathrm{mg} / \mathrm{g}$ at 180 minutes. The adsorption capacity of $5.31 \mathrm{mg} / \mathrm{g}$ for $\mathrm{Zn}(\mathrm{II})$ o FA is 
higher than the values found by other researchers for the adsorption of zinc onto fly ash [20,21], but is very closed to $\mathrm{q}_{\mathrm{e}}=4.505 \mathrm{mg} / \mathrm{g}$ obtained by reference [22]. The adsorption capacity of $19.9 \mathrm{mg} / \mathrm{g}$ for $\mathrm{Pb}(\mathrm{FA})$ is closed to the value $18.8 \mathrm{mg} / \mathrm{g}$ obtained by authors [20].

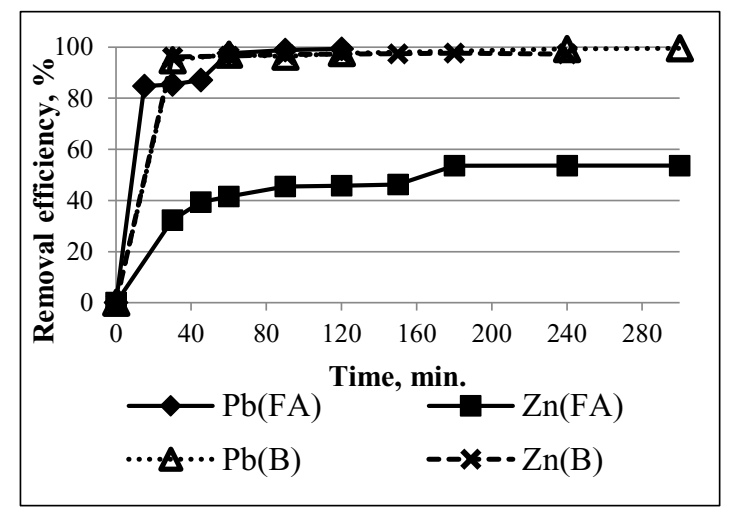

Fig. 11. Effect of contact time on the $\mathrm{Pb}(\mathrm{II})$ and $\mathrm{Zn}$ (II) removal efficiency on bentonite (B) and fly ash(FA).

The adsorption capacity obtained for $\mathrm{Pb}(\mathrm{B})$ was 8.96 $\mathrm{mg} / \mathrm{g}$ at 30 minutes. The adsorption capacity obtained by different authors varies between 7.56 and $16.30 \mathrm{mg} / \mathrm{g}$ $\mathrm{Pb}$ (II) on bentonite, as function of the initial concentration of the solution and the type of bentonite used in process [23-25].

The adsorption capacity obtained for $\mathrm{Zn}(\mathrm{B})$ was $10.88 \mathrm{mg} / \mathrm{g}$ at 120 minutes. The adsorption capacity obtained by different authors varies between 3.24 and $11.84 \mathrm{mg} / \mathrm{g}$ [26-28] Zn(II) on bentonite, as function of the type of bentonite used in process.

The results showed that bentonite adsorb better $\mathrm{Zn}(\mathrm{II})$ and fly ash $\mathrm{Pb}(\mathrm{II})$.

\section{Conclusions}

This paper presented the chemical, structural and morphological characteristic of the bentonite and fly ash from Romania. These materials are suitable for uptake of $\mathrm{Pb}$ (II) and $\mathrm{Zn}(\mathrm{II})$ ions from aqueous solutions.

The removal capacity of fly ash increases with $\mathrm{pH}$, when $\mathrm{pH}$ is between 2.5 and 5 . and after that, remains constant. The removal capacity of bentonite doesn't depend on $\mathrm{pH}$.

The adsorption capacity of fly ash towards $\mathrm{Pb}$ (II) ions is $19.9 \mathrm{mg} / \mathrm{g}$ and $5.31 \mathrm{mg} / \mathrm{g}$ for $\mathrm{Zn}$ (II).

The adsorption capacity of bentonite is $8.96 \mathrm{mg} / \mathrm{g}$ for $\mathrm{Pb}$ (II) and $10.88 \mathrm{mg} / \mathrm{g}$ for $\mathrm{Zn}$ (II).

The fly ash has a higher affinity for $\mathrm{Pb}$ (II) ions while bentonite for $\mathrm{Zn}(\mathrm{II})$.

The authors thank for financial support given by Ministry of Education and Research, through National Authority for Scientific Research and Innovation (ANCSI), within the NUCLEU research project. Special thanks for Victor FRUTHOPRISAN, Cornel MUNTEANU from Institute of Physical Chemistry "Ilie Murgulescu” Bucharest, Romania.

\section{References}

1. U. Nadeem, M. Datta, Eur.Chem. Bull, 3, 7 (2014)

2. AO. Dada, AP. Olalekan, AM. Olatunya, O. Dada, IOSR J. of Applied Chem., 3, 1 (2012)

3. Ye Hengpeng and Yu Zhijuan, Nat. Res., 1 (2010)

4. T. Matsi, VZ. Jeramidas, Environmental Pollution, 104 (1998)

5. Satya Vani Yadla, Stridevil V, Chandana Lakshmi MVV, J of Chem., Biol and Physical Sci., 2, 3 (2012)

6. M. Ulmanu, T. Matsi I. Anger, E. Gament, G. Olanescu, C. Predescu, M. Sohaciu, U.P.B. Sci. Bull., Series B, 69, 2 (2007)

7. H. Bradl, Encyclopedia of Surface and Colloid Science (Ed. Marcel Dekker, 2002)

8. Y. Fernandez-Nava, M. Ulmanu, I. Anger, E. Maranon, L. Castrillon, Water Air Soil Pollut., 215, (2011)

9. T.S. Malarvizhi, T. Santhi., J. of Water Resource and Protection, 5, (2013)

10. Kumar Saroj, A.K. Mishra, M. Upadhyay, D. Singh, M. Mishra and Kumar Sujata, Int. Res. J. of Env, Sci, 3, 2 (2014)

11. S.O. Bada and S. Potgieter- Vermaak, Leonardo Electronic J. of Practices and Technol., 12 (2008)

12. A. K. Agarwal, M. S Kadu, C. P. Pandhurnekar, I.L. Muthreja, The Holistic Approach to Env, 4, 1 (2014)

13. F.G. Alabarse, R.V. Conceicao, N.M. Balzaretti, F. Schemato, A.M. Xavier, Applied Clay Science, 51 (2011)

14. C.M. Kede, M.A. Etoh, PP. Ndibewu H.M. ngomo, P.M. Ghogomu, British J. Applied Sci. Technol., 4(7), 1071-1088 (2014)

15. M. Barkat, S. Chegrouche1, A. Mellah, B. Bensmain, D. Nibou, M. Boufatit, J. of Surface Engineered Mat.,Adv. Technol., 4 (2014)

16. L. Aloui F. Ayan, A. Ben Othman, M. TrabelsiAyadi, Internat J. of Eng. and Appl. Sci. (IJEAS) 2, 7, (2015)

17. Ministerial Order no. 95/2005 (Env. and Water Manag. Ministry)

18. T.S. Malarvizhi, T. Santhi, J. Res. Chem. Intermed, 39 (2013)

19. M. Moyo, L. Muguni, B.C. Nyamunda, Int. J. of Eng. Sci and Technology, 4, 4 (2012)

20. P. Ricou, I. Lecuyer and P. Le Cloired, Env Technology, 19 (1998)

21. G.M. Taha, Ground Water Monitoring\& Remediation, 26, 4 (2006)

22. A. K. Agarwal, M.S. Kadu, C.P. Pandhurnekar, I.L. Muthreja, Int. J. of Environ. Sci. and Develop., 3, 4 (2012)

23. S. Melichova, L.Hromada, Pol. J. Environ. Stud., 22, 2(2013) 
24. S.L. Bailey, T.J. Olin, K.M. Bricka, D.D. Adrian, Water Res., 33 (1999)

25. O. Abolino, M. Aceto, M. Malandrino, C. Sarzanini, E. Mentasti, Water Res., 37 (2003)

26. M. Larakeb, L. Youcef, S. Achour, Athens J of Science, 4, 1( 2017)
27. G. A. Tito, L. H. G. Chaves, R. S. De Souza, Rev. CAATINGA, 21, 5 (2008)

28. W. Chai, Y. Huang, S. Su, G. Han, J. Liu, Y. Cao, Phys. Problems of Mineral Proc., 53, 1 (2017) 